\title{
Effect of a Prebrushing Mouthwash on Color Stability of Composite Resins
}

\section{Efeito de um Evidenciador de Placa na Estabilidade de Cor de Resinas Compostas}

\author{
Ângela Dalla Nora ${ }^{\mathrm{a}}$; Camila da Silva Rodrigues*b; Rachel de Oliveira Rocha ${ }^{\mathrm{a}}$ \\ ${ }^{a}$ Universidade Federal de Santa Maria, Stricto Sensu Graduate Program in Dental Sciences.RS, Brasil. \\ ${ }^{b}$ Universidade Estadual Paulista, Instituto de Ciência e Tecnologia. SP, Brasil. \\ *E-mail: camilasrdg@gmail.com
}

\begin{abstract}
Despite composite resins capacity to mimic dental tissues, they can discolor over time. However, there is no information on the effect of prebrushing mouthwashes on the composite resin staining. This study aimed to evaluate the effect of prebrushing mouthwashes on the color stability of three composite resins. Twenty specimens of each resin were prepared: Filtek Z250 (3M ESPE -S Paul, MN, USA), Charisma (Heraeus Kulzer GmbH - Hanau - Germany) e EvoluX (Dentsply- Petrópolis - Brazil). Groups were randomly divided accord to the treatment: immersion in prebrushing mouthwash (test group) or immersion in deionized water (control group). Test groups were immersed in $10 \mathrm{ml}$ of prebrushing mouthwash Plax Magic (Colgate-Palmolive, São Bernardo do Campo, SP, Brazil) for $60 \mathrm{~s}$ three times a day during 35 days following the manufacturer's instructions. Color measurements were performed after $24 \mathrm{~h}$ of specimen's preparation and after 7, 14, 21, and 35 days of immersion time. Results showed that prebrushing mouthwash Plax Magic promoted a color change in all the tested materials and evaluation time. The color change was greater in composite resin Charisma, followed by Z250 and EvoluX. Therefore, prebrushing mouthwash promoted a color change in all the materials used. Composite resin Charisma demonstrated less color stability than Filtek Z250 resin and EvoluX resin, which was the most stable.
\end{abstract}

Keywords: Composite Resins. Oral Hygiene. Color.

\section{Resumo}

Apesar da capacidade das resinas compostas de mimetizar os tecidos dentais, esses materiais podem ter sua cor alterada com o tempo. No entanto, não há informação na literatura sobre o efeito de evidenciadores de placa na estabilidade de cor desses materiais. Este estudo teve por objetivo avaliar o efeito de um evidenciador de placa na estabilidade de cor e três resinas compostas. Para isso, 20 espécimes de cada resina foram preparados: Filtek Z250 (3M ESPE -S Paul, MN, EUA), Charisma (Heraeus Kulzer GmbH - Hanau - Alemanha) e EvoluX (Dentsply-Petrópolis - Brasil). Os grupos foram aleatoriamente divididos de acordo com o tratamento a ser submetido: imersão no evidenciador de placa (grupo teste) ou imersão em água deionizada (grupo controle). Os grupos teste foram imersos em $10 \mathrm{ml}$ do evidenciador de placa Plax Magic (Colgate-Palmolive, São Bernardo do Campo, SP, Brasil) por $60 \mathrm{~s}$ três vezes por dia durante 35 dias, de acordo com a orientações de uso do fabricante. As leituras de cor foram feitas após 24 h da preparação dos espécimes e após 7, 14, 21 e 35 dias de imersão. Os resultados mostraram que o evidenciador de placa Plax Magic promoveu alteração de cor em todos os materiais usados e em todos os tempos de leitura. A alteração de cor foi maior na resina Charisma, seguida da Z250 e EvoluX. Portanto, o evidenciador de placa promove alteração de cor em todos os materiais testados. A resina composta Charisma demonstrou menor estabilidade de cor que as resinas Z250 e EvoluX, que, por sua vez, foi a mais estável.

Palvras-chave: Resinas Compostas. Higiene Oral. Cor.

\section{Introduction}

Nowadays, the requirement of dental patients to restore not only function but also teeth esthetics became part of the dentist's routine. Resin composites have been highly used as an esthetic restorative material due to their capacity to simulate dental structure naturally, accessible cost, color variability, and optical characteristics enough to replace dental tissues. ${ }^{1}$

On the other hand, composite resins tend to discolor in the oral environment because of intrinsic or extrinsic factors. Intrinsic factors are related to the material itself, including factors such as alteration on the interface between the matrix and filler particles and on resinous matrix. ${ }^{2}$ Extrinsic factors are related to pigments of patient's diet and oral hygiene products which can be absorbed by the resinous matrix. ${ }^{3}$ Previous studies report that pigments absorption is related to hydrophilic/hydrophobic characteristics of organic matrix components of composite resins. ${ }^{4,5}$

Oral mouthwashes have been largely used due to the search for benefits in plaque control, gingivitis prevention, and good breath. ${ }^{6}$ For children, mouthwashes used to identify plaque before brushing are more than an oral hygiene device, they can be a factor to encourage brushing by helping plaque identification and serving as a guide to better brushing. ${ }^{7,8}$ Nevertheless, literature shows that in a short time ${ }^{9}$ mouthwashes can promote restorative materials degradation and softening, favoring the internal discoloration and pigments 
retention, which causes staining of restorations. ${ }^{10}$

Lepri et al. ${ }^{11}$, in a study involving three mouthwashes and one composite resin, observed that all the solutions promoted color changes in 30 days ( $1 \mathrm{~min} /$ day). In addition, Festuccia et al. ${ }^{3}$ evaluated the effect of four mouthwashes on the color, roughness, and hardness of two composite resins and concluded that alterations were influenced by material and mouthwashes used. However, there is a lack of information on the effects of prebrushing mouthwashes on color stability of restorative materials.

In this context, this study aimed to evaluate the effect of prebrushing mouthwashes indicated to children on the color stability of three composite resins. The tested hypotheses were: 1) composite resins used would present different color stability after the action of prebrushing mouthwash and 2) Prebrushing mouthwash would promote greater color change than deionized water.

\section{Material and Methods}

\subsection{Study design}

The factors involved in this in vitro study were: composite resin (3 levels: Filtek Z250 - 3M ESPE, St Paul, USA, Charisma - Heraeus Kulzer GmbH, Hanau, Germany or EvoluX - Dentsply, Petrópolis, Brazil), storage media (2 levels: prebrushing mouthwash Plax Magic - ColgatePalmolive, São Bernardo do Campo, Brazil or deionized water) and time (7, 14, 21 and 35 days). The materials used in this study are described in Table 1.

Table 1 - Materials used in this study

\begin{tabular}{|c|c|c|c|c|}
\hline \multirow{2}{*}{ Material } & \multicolumn{3}{|c|}{ Composition* } & \multirow{2}{*}{ Manufacturer } \\
\hline & Type & Matrix & Filler particle & \\
\hline Filtek Z250 & microhybrid & $\begin{array}{l}\text { Bis-GMA, UDMA, } \\
\text { Bis-EMA }\end{array}$ & $\begin{array}{l}\text { Zirconia, Silica } 0.6 \mu \mathrm{m} \\
60 \%\end{array}$ & $\begin{array}{c}\text { 3M-ESPE, St Paul, MN, } \\
\text { USA }\end{array}$ \\
\hline EvoluX & nanohybrid & $\begin{array}{l}\text { Bis - GMA, } \\
\text { Bis-EMA }\end{array}$ & Silica nanoparticles $58 \%$ & $\begin{array}{l}\text { Dentisply Commerce } \\
\text { and Industry Ltda. } \\
\text { Petrópolis, RJ, Brazil }\end{array}$ \\
\hline Charisma & microhybrid & Bis-GMA & $\begin{array}{l}\text { Silicon dioxide }(0.02- \\
0.07 \mu \mathrm{m}) \text {, barium glass, } \\
\text { aluminum, fluoride } \\
(0.02-2 \mu \mathrm{m}) 58 \%\end{array}$ & $\begin{array}{l}\text { Heraeus Kulzer GmbH, } \\
\text { Hanau, Germany }\end{array}$ \\
\hline Plax Magic & \multicolumn{3}{|c|}{$\begin{array}{c}\text { Water, glycerin, propylene glycol, sorbitol, poloxamer 407, cetylpyridinium } \\
\text { chloride, flavor, sodium fluoride, methyl paraben, sodium saccharin, menthol, } \\
\text { propylparaben, CI } 42090\end{array}$} & $\begin{array}{l}\text { Colgate-Palmolive, São } \\
\text { Bernardo do Campo, SP, } \\
\text { Brazil }\end{array}$ \\
\hline
\end{tabular}

*manufacturer's information.

Source: Research data.

\subsection{Specimens' preparation}

Twenty specimens of each resin were prepared (Filtek Z250, Charisma, and EvoluX) were prepared with a metallic fit matrix with a central hole on dimensions of $8 \mathrm{~mm} \times 2 \mathrm{~mm}$ positioned above a polyester strip. The composite increment was inserted on the matrix and covered by another polyester strip and a glass sheet. Constant load (500 g) was applied per $30 \mathrm{~s}$ to press material and promote standard thickness. The composite was photoactivated with LED (Emmiter, Shuster - Santa Maria, Brazil) during $40 \mathrm{~s}$ (potency about $800 \mathrm{~mW} /$ $\mathrm{cm}^{2}$ ). Immediately after polymerization, the specimens were submitted to polish with discs Sof-lex Pop On/ orange series (3M-ESPE - St. Paul-MN - USA) on granulation superfine, per $20 \mathrm{~s}$ each disc. Procedures were realized by the same operator previously trained. All the specimens were stored in deionized water in bottles sealed at a constant temperature $\left(37^{\circ} \mathrm{C}\right)$ for $24 \mathrm{~h}$.

After an initial 24-h period, the specimens of each resin were randomly divided $(n=10)$ according to the treatment: immersion in prebrushing mouthwash (test group) or deionized water (control group). The test groups were immersed in $10 \mathrm{ml}$ of prebrushing mouthwash Plax Magic (Colgate-Palmolive,
São Bernardo do Campo, SP, Brazil) per $60 \mathrm{~s}$ three times a day $^{11}$ during 35 days. After each prebrushing mouthwash exposition, the specimens were washed in running water, dried with paper, and returned to sealed bottles. The control groups were kept in deionized water during the study period. The water of each bottle was changed every two days to avoid bacteria or yeast contamination. ${ }^{4}$

\subsection{Color parameters evaluation}

Color measurements were realized at baseline, 7, 14, 21 , and 35 days of immersion in the mouthwash, using a spectrophotometer SP60 (X-Rite - Grand Rapids / MI, United States) on analyzing mode, D-65 illuminant, $10^{\circ}$ observer angle, and CIEL*a*b* color space (Commission International $1^{\prime}$ Eclairage). On this system, $\mathrm{L}^{*}$ is the luminosity axis with values varying from zero (black) to one hundred (white), and $\mathrm{a}^{*}$ and $\mathrm{b}^{*}$ are color coordinates in the green-red axis and in the blue-yellow axis, respectively. Measurements were realized over a white background (AG-5330, BYK Gardner, USA). A coupling substance (glycerol C3H8O3/ Vetec Química Fina Ltda, Rio de Janeiro, RJ Brazil) with a refraction index (n) around 1.47 was used to minimize light 
scattering between the specimen and the sheet background. First, the spectrophotometer was calibrated according to the manufacturer's guidelines. For each specimen, $L^{*} a^{*} b^{*}$ parameters readings were repeated three times, and the median of those readings was used in the analysis. The color change was calculated with the CIELAB equation (Equation 1).

$$
\Delta E_{a b}=\sqrt{\Delta L^{2}+\Delta a^{2}+\Delta b^{2}}
$$

The clinical perceptibility y and unacceptability thresholds obtained by Paravina et al. ${ }^{12}$, in which $\Delta \mathrm{E}_{\mathrm{ab}}=1.2$ corresponds to perceptibility level and $\Delta \mathrm{E}_{\mathrm{ab}}=2.7$ corresponds to clinical unacceptability level, were considered.

\subsection{Statistical analysis}

Statistical analysis was carried out using the software Statistica version 7.0 (StatSoft, Palo Alto, CA, USA). First, color change $\left(\Delta E_{a b}\right)$ values had normality (Shapiro-Wilk's test) and homoscedasticity (Levene's test) tested. Data were submitted to multiple analysis of variance (MANOVA) including the factors storage media, resin composite, storage time, and color change as outcome.

\section{Results and Discussion}

Table 2 shows the color change $(\Delta \mathrm{E})$ mean values and standard deviation of each group in all the study points $(7,14$, 21 , and 35 days). No statistically significant difference was observed in the comparison between times and treatments in the groups aged in water.

Table 2 - Means and standard deviations of color change $\left(\Delta \mathrm{E}_{\mathrm{ab}}\right)$ of each experimental group

\begin{tabular}{|c|l|l|l|l|l|}
\hline & & \multicolumn{1}{|c|}{ 7 days } & \multicolumn{1}{c|}{ 14 days } & \multicolumn{1}{c|}{ 21 days } & \multicolumn{1}{c|}{ 35 days } \\
\hline \multirow{3}{*}{$\begin{array}{c}\text { Water } \\
\text { (control) }\end{array}$} & Filtek Z250 & $1.48(0.68)^{\mathrm{A}, \mathrm{b}}$ & $1.30(0.91)^{\mathrm{A}, \mathrm{b}, \mathrm{c}}$ & $1.47(0.89)^{\mathrm{A}, \mathrm{b}, \mathrm{c}}$ & $1.67(0.94)^{\mathrm{A}, \mathrm{b}, \mathrm{c}}$ \\
\cline { 2 - 6 } & Charisma & $1.03(0.56)^{\mathrm{A}, \mathrm{b}}$ & $0.92(0.44)^{\mathrm{A}, \mathrm{c}}$ & $1.32(0.75)^{\mathrm{A}, \mathrm{b}, \mathrm{c}}$ & $1.34(0.66)^{\mathrm{A}, \mathrm{c}}$ \\
\cline { 2 - 7 } & Evolu-X & $0.99(0.43)^{\mathrm{A}, \mathrm{b}}$ & $1.16(0.55)^{\mathrm{A}, \mathrm{b}, \mathrm{c}}$ & $0.90(0.36)^{\mathrm{A}, \mathrm{c}}$ & $1.60(0.70)^{\mathrm{A}, \mathrm{b}, \mathrm{c}}$ \\
\hline \multirow{2}{*}{$\begin{array}{c}\text { Prebrushing } \\
\text { mouthwash }\end{array}$} & Filtek Z250 & $2.85(1.66)^{\mathrm{B}, \mathrm{b}}$ & $3.79(1.35)^{\mathrm{A}, \mathrm{B}, \mathrm{b}}$ & $3.98(2.01)^{\mathrm{A}, \mathrm{B}, \mathrm{b}}$ & $4.23(1.84)^{\mathrm{A}, \mathrm{b}}$ \\
\cline { 2 - 7 } & Charisma & $5.87(1.28)^{\mathrm{C}, \mathrm{a}}$ & $8.02(1.31)^{\mathrm{B}, \mathrm{a}}$ & $8.84(1.29)^{\mathrm{A}, \mathrm{B}, \mathrm{a}}$ & $9.42(1.70)^{\mathrm{A}, \mathrm{a}}$ \\
\cline { 2 - 7 } & Evolu-X & $1.24(0.95)^{\mathrm{A}, \mathrm{b}}$ & $1.63(0.72)^{\mathrm{A}, \mathrm{b}, \mathrm{c}}$ & $1.47(0.62)^{\mathrm{A}, \mathrm{b}, \mathrm{c}}$ & $1.74(0.80)^{\mathrm{A}, \mathrm{b}, \mathrm{c}}$ \\
\hline
\end{tabular}

Upper case letters within a row indicate statistical differences among the measurements of the same group. Lower case letters within a column indicate statistical differences among the treatments. $(\mathrm{P}<0.05)$

Source: Research data.

Comparisons among the test groups regarding storage time (stored in the mouthwash) showed that Filtek Z250 presented statistically significant color change only after the last measurement (35 days).In contrast, Charisma presented significant color change since 14 days of storage, and EvoluX did not present significant color change over time. In all the measurements, Charisma stored in the mouthwash presented greater color change and Evolu-X was similar to the groups stored in water. Regarding clinical thresholds, only Charisma and Filtek Z250 aged in the mouthwash reached $\Delta \mathrm{E}_{\mathrm{ab}}=2.7$ (clinical unacceptability threshold).

Resin composites presented different color stability behaviors when immersed daily in the prebrushing mouthwash, leading to acceptance of the first tested hypothesis. At all the evaluation times, EvoluX composite had color more stable than the others did, and Charisma was the least stable one. Previous studies ${ }^{13}$ concluded that composites color stability is material dependent, and may be associated with filler particles type ${ }^{14}$. The manufacturer classifies EvoluX as a nanohybrid due to the small size of its particles. Therefore, a smaller size allows a higher number of particles by volume, reducing the free available volume of the organic matrix for water sorption and, consequently, pigments. $^{15}$

Comparing storage time, EvoluX resin was the only one to keep its color stable in all the measurements without reaching the clinical acceptability threshold $(\Delta \mathbf{E a b}=$ 2.7). ${ }^{12}$ On the other hand, Filtek $\mathrm{Z} 250$ reached $\Delta \mathrm{E}$ values over 2.7 , but it maintained stability until the penultimate measurement and had a significant color change after 35 days of daily immersions. Charisma resin also reached the clinical acceptability thresholds since the first week of contact with the prebrushing mouthwash, and the values significantly increased after 14 days, and even more after 35 days. The difference in color stability of composite resins used can be influenced by sorption. ${ }^{16}$ Composites that have high Bis-GMA (bisphenol glycidyl methacrylate) levels, for example, are considered vulnerable to staining due to the monomer hydrophilicity. ${ }^{17}$ In addition, other monomers as UDMA presents higher resistance to staining because of their hydrophobicity. ${ }^{18}$ Charisma organic matrix is composed of Bis-GMA, which may have contributed to the highest $\Delta \mathrm{E}$ values in this study.

The highest color change values were observed in test groups, which supports the second hypothesis. The control groups of all the resins presented perceptible values $\left(\Delta \mathrm{E}_{\mathrm{ab}}>1.2\right)^{12}$, but they did not reach clinical unacceptable values. No significant differences were also observed in times or analysis of treatments interactions. Therefore, no tested resin had color stability higher than the other when kept in water. These findings emphasize the influence of external factors, as the degradation caused by pigments absorption, on color stability of composite resins. ${ }^{19}$

The present study observed that prebrushing mouthwash Plax Magic significantly affected the color stability of the most evaluated resins. Mouthwashes can be composed of detergents, 
emulsifiers, water, antimicrobial agents, salts, and alcohol. ${ }^{20}$ These components may affect the composite resins polymeric matrix causing degradation and softening, favoring pigments retention and, consequently, color change ${ }^{21-23}$. According to Gurgan et al. ${ }^{10}$ mouthwashes may affect the composite resin properties regardless of alcohol concentration or existence.

A previous study a with similar methodology evaluated the color stability of composite resins after contact with mouthwashes and did not observe values of $\Delta \mathrm{E}_{\mathrm{ab}}>2.7$; however, none of them used a prebrushing mouthwash. ${ }^{3}$ Therefore, due to the lack of evidence about the effect of prebrushing mouthwashes on restorative materials, more in vitro and in vivo studies are needed to complement the findings herein and clarify the interaction among these factors.

\section{Conclusion}

Plax Magic prebrushing mouthwash promoted significant color changes in the tested composite resins. Charisma resin presented lower color stability over time, whereas Filtek Z250 and EvoluX were more stable.

\section{Acknowledgements}

The authors are thankful to the Research Support Fund of the Federal University of Santa Maria (FIPE/UFSM) for the grant of a scholarship.

\section{References}

1. Lepri CP, Palma RG. Surface roughness and color change of a composite: Influence of beverages and brushing. Dent Mater J 2012;31(4):689-96. doi: https://doi: 10.4012/dmj.2012-063.

2. Cagatay B, Mehmet Y. Intrinsic and extrinsic discoloration of imethacrylate and silorane based composites. J Dent 2012;40s:57-63. doi: https://doi: 10.1016j.jdent.2011.12.017.

3. Festuccia MSCC, Garcia LFR, Cruvinel DR, Pires-de-Souza FCP. Color stability, surface roughness and microhardness of composites submitted to mouthrinsing action. J Appl Oral Sci 2012;20(2):200-5. doi: https://doi: 10.1590/s167877572012000200013.

4. Ardu S, Braut V, Gutemberg D, Krejci I, Dietschi D, Feilzer AJ. A long-term laboratory test on staining susceptibility of esthetic composite resin materials. Quintessence Int 2010;41(8):695-702.

5. Stawarczyk B, Sener B, Trottmann A, Roos M, Özcan M, Hämmerle CHF. Discoloration of manually fabricated resins and industrially fabricated CAD/ CAM blocks versus glassceramic: effect of storage media, duration, and subsequent polishing. Dent Mater J 2012;31(3):377-83. doi: https://doi: 10.4012/dmj.2011-238.

6. Addy M, Renton-Harper P, Warren P, Newcombe RG. An evaluation of video instruction for an electric toothbrush. Comparative single-brushing cross-over study. J Clin Periodontol 1999;26:289-93. doi: https://doi: 10.1034/j.1600051x.1999.260505.x.

7. Marsh PD, Martin MV. Oral microbiology. London; 1992.

8. Sagel PA, Lapujade PG, Miller JM, Sunberg RJ. Objective quantification of plaque using digital image analysis. Monogr Oral Sci 2000;17:130-43. doi: https://doi: 10.1159/000061638.

9. Santos PA, Palma-Dibb RG, Corona SAM. Influence of fluoride containing solutions on the translucency of flowable composite resins. J Mater Sci 2003;38:3765-8. doi: https:// doi.org/10.1023/A:1025928116563

10. Gurgan S, Onen A, Koprulu H. In vitro effects of alcoholcontaining and alcoholfree mouthrinses on microhardness of some restorative materials. J Oral Rehabil 1997;24:244-6

11. Lepri CP, Ribeiro MVM, Dibb A, Palma-Dibb RG. Influence of mounthrinse solutions on the color stability and microhardness of a composite resin. Int $\mathbf{J}$ Esthet Dent 2014;9:238-246.

12. Paravina RD, Ghinea R, Herrera LJ, Bona AD, Igiel $C$, Linninger M, et al. Color difference thresholds in dentistry. $\mathrm{J}$ Esthet Restor Dent 2015:S1-9. doi: 10.1111/jerd.12149.

13. Villalta P, Lu H, Okte Z, Garcia-Godoy F, Powers JM. Effects of staining and bleaching on color change of dental composite resins. J Prosthet Dent 2006;95:137-42. doi: https://doi: 10.1016/j.prosdent.2005.11.019.

14. Lee YK. Influence of filler on the difference between the transmitted and reflected colors of experimental resin composites. Dent Mater 2008;24:1234-47. doi: https://doi: 10.1016/j.dental.2008.01.014.

15. Vichi A, Ferrari M, Davidson CL. Color and opacity variations in three different resin-based composite products after water aging. Dent Mater 2004;20:530-4. doi: Https://doi: 10.1016/j. dental.2002.11.001.

16. Soares-Geraldo D, Scaramucci T, Steagall-Jr W, Braga SRM, Sobral MAP. Interaction between staining and degradation of a composite resin in contact with colored foods. Braz Oral Res 2011;25(4):369-75. doi: https://doi:10.1590/s180683242011000400015 .

17. Kalachandra S, Turner DT. Water sorption of polymethacrylate networks: bis-GMA/TEGDM copolymers. J Biomed Mater Res 1987;21:329-38. doi: https://doi: 10.1002/jbm.820210306.

18. Ho CT, Vijayaraghavan TV, Lee SY, Tsai A, Huang HM, Pan LC. Flexural behaviour of post-cured composites at oralsimulating temperatures. J Oral Rehabil 2001;28:658-67. http://doi: 10.1046/j.1365-2842.2001.00734.x.

19. Dietschi D1, Campanile G, Holz J, Meyer JM. Comparison of the color stability of ten new-generation composites: an in vitro study. Dent Mater 1994;10:353-62. doi: https://doi: 10.1016/0109-5641(94)90059-0.

20. Moran JM. Chemical plaque control-prevention for the masses. Periodontol 2000 1997;15:109-17. doi: https://doi: 10.1111/j.1600-0757.1997.tb00110.x.

21. Settembrini L, Penugonda B, Scherer W, Strassler H, Hittelman E. Alcohol-containing mouthwashes: effect on composite color. Oper Dent 1995;20:14-7.

22. Eliades GC, Tzoutzas JG, Vougiouklakis GJ. Surface alterations on dental restorative materials subjected to an airpowder abrasive instrument. J Prosthet Dent 1991;65:27-33. doi: https://doi: 10.1016/0022-3913(91)90042-u.

23. Mante F, Salleh N, Mante M. Softening patterns of post-cure heat-treated dental composites. Dent Mater1993;9:325-31. doi: https://doi: 10.1016/0109-5641(93)90051-q. 